\title{
THE ATTITUDE OF PUBLIC POLICY TOWARDS THE CONTRACTS OF HEIRS EXPECTANT AND REVERSIONER.
}

WHAT IS PUBLIC POLICY?

Government is dependent upon social organization, but neither government nor the social fabric constitute the State, for both may entirely change or disintegrate and the State maintain its identity. The State is the body politic; the sovereign; the recipient of the individual's freedom, and the trustee thereof for the citizen. Government is the beneficent exercise of this trust. The social fabric is the means whereby this trust is exercised or preserved. The public weal is the health of the social fabric. Public policy is the requirement that the social fabric shall be maintained inviolate.

When acts of the individual are prohibited as being opposed to public policy, their intrinsic morality or immorality is not considered, nor is their effect on the individual, but solely their effect to impair the social fabric. But one question is presented: Does their consummation tend to injuriously affect the public weal? If the question be answered affirmatively, then the performance of the act is impliedly forbidden to the citizen, and any obligation arising from the act is unenforceable. If the general tendency of such acts is injurious, then public policy regards them with disfavor. Obligations arising therefrom are presumptively invalid and it is incumbent upon him who would enforce such obligation to show that its effect is not injurious.

But the structure of the social fabric may so change that the acts of individuals which once threatened its well-being may cease to affect it in any particular, and hence the public policy of the eighteenth may not be the policy of the twentieth century; nor the public policy of England the policy of America.

THE EFFECT OF CONTRACTS OF EXPECTANTS AND REVERSIONERS-HOW

$$
\text { FAR IDENTICAL. }
$$

Before we undertake the consideration of public policy towards the contracts of reversioner and heir expectant, we will make some 
examination into the relation of such contracts the one to the other. The reversioner has an estate on a future contingency, viz: that he outlives the tenant for years. His interest during the tenant's life is present and may be conveyed at law. The heir expectant has no present interest in his ancestor's estate. It is a mere expectancy, existing not by right in him, but by the ancestor's favor. It cannot be conveyed at law, but an attempted conveyance is recognized by the Chancery courts ás an equitable assignment; it is considered to be a contract to convey the estate of the ancestor when it shall vest in the expectant, and as such it may be specifically enforced. ${ }^{2}$ The effect of both classes of contracts being identical inasmuch as the fee is diverted from the heir, it follows that public policy towards both must be the same, and while considering such policy they may be considered as identical. ${ }^{2}$

In Carleton v. Leighton, 3 Meriv., 667 (1805), the Lord Chancellor said: "That the expectancy of an heir presumptive or apparent (the fee simple being in the ancestor) was not an interest or a possibility, nor was capable of being made the subject of assignment or contract; that the cases cited were cases of covenant to settle or assign property which should fall to the covenantor; when the interest which passed by the covenant was not an interest in the land but a right under the contract"; and in 1833, Lyde v. Mynn, I Myl. \& K, 683, it was held that, "What Carleton v. Leighton actually decides * * * is this: Not that a person may not validly deal with an expectancy and bind himself to convey it when his title shall àccrue, but only that such obligation is merely personal. $\mathrm{He}$ is bound and he may be compelled to perform the contract when he can." See, also, Hobson v. Trevor, $2 \mathrm{P}$. Wms. 191 ; Wright v. Wright, I Ves. Sr., 409; Whitfield v. Fausset, I Ves. Sr., 387; Medcalf v. Ives, I Atk., 63; Beckley v. Nezuland, 2 P. Wms., 182; Carleton v. Leighton, Supra, reporter's note; Wethered v. Wethered, 2 Sim, 183; Harwood v. Tooke, 3 Sim, 192; Story, Equity Juris., ro4oc; Fitzgerald v. Vestal, 4 Stieed, 258; McDonald v. McDonald, 5 Jones Eq. (N. C.), 2II; Mastin v. Marlow, 65 N. C., 695; Haverus v. Thompson, 26 N. J. Eq., 383; Barham v. McKneely, $89 \mathrm{Ga} ., 8 \mathrm{I2}$; Stover v. Eycleshimer, 4 Abb. Dec., 309; Steele v. Frierson, 85 Tenn., 430; In re Garcelon, 104 Cal., 570; Walker v. Walker, 67 Pa. St., I85; Kuhn's Appeal, I63 Pa. St., 438; Power's Appeal, $63 \mathrm{~Pa}$. St., 443 ; Bayler v. Com., $40 \mathrm{~Pa}$. St., 37 ; Wilson's Estate, $2 \mathrm{~Pa}$. St., 325 ; Parsons v. Ely, 45 Ill., 232; Bishop v. Davenport, 58 IIl., 105; Cleridenning v. Wyatt, 54 Kan., 523; Hale v. Hollon, 35 S. W., 843.

"sit was old, I conceive, necessary for the purpose of bringing the case within the old law as to bargains with expectant heirs, that the so-called heirs should have any vested or defined reservations." Earl of Aylesford v. Morris, L. R, $8 \mathrm{Ch} ., 484$. "The doctrine applies *** not merely to heirs dealing with expectancies, but to reversioners and remainder-men dealing with property already vested in them, but of which the enjoyment is future." Story, Eq. Juris., Sec. 337. 
THE ENGLISH RULES GOVERNING SUCH CONTRACTS.

In the earlier English cases these contracts were looked upon with disfavor, as it was considered that their general effect upon the public weal was injurious. Accordingly, the presumption was against their validity, and the burden of proof to establish such validity was placed upon him who sought to enforce the contract. As was said by Lord Chancellor Eldon in Davis v. Duke of Marlborough (2 Swan., 108, 139): "If a person has" dealt with an heir apparent, for an interest of which he is not in present possession, this court extends to the heir the benefit of this principle with reference to those dealing with him, that it does not rest on him to show that the bargain was unreasonable and improvident, but on them to show that it was reasonable." And Lord Chancellor Hardwicke said in Earl of Chesterfield v. Janssen (2 Ves., Sr., 124, I56): "The last head of fraud on which there has been relief, is that which infects catching bargains with heirs, reversioners or expectants, in the life of the father, etc., against which relief always is extended. *** There is always fraud presumed or inferred from the circumstances or conditions of the parties contracting; weakness on one side, usury on the other, or extortion or advantage taken of that weakness." And it was held that a third element must be shown: that the consideration was full and adequate. As was said by Sir William Grant, M. R., in Gowland v. De Faria (I7 Ves., Jr., 20): "It is incumbent upon those who have dealt with an expectant heir relative to his reversionary interest, to make good the bargain; that is, to be able to show that a full and adequate consideration was paid."

But it is evident that the presumption of fraud does not arise from the fact that one is contracting for delivery of an expectancy or that he is seeking to relieve necessitous circumstances by discounting the future, for fraud is not presumed in the case of ordinary commercial contracts for future delivery, nor when one in order to satisfy his present wants borrows money at a high rate of interest. The reason for this anomalous rule that the burden is on him seeking to enforce the contract rests on public policy.

THE PUBLIC POLICY OF THESE CONTRACTS-ITS ORIGIN.

What is this public policy? How do these contracts tend to injure the social fabric? To answer the question one must consider 
the political structure of England during the I7th and I8th centuries, when the doctrine was first enunciated. England was slowly emerging from a condition of qualified feudalism, introduced by the Normans. Under the feudal law real property was in fact as well as in name the royal property and was the foundation on which the social fabric was built. Practically all land tenures rested on actual or prescriptive grants from the crown. These grants had been made for personal services rendered the crown and their descent was ordinarily secured in the family of the grantee by entails or analogous systems. The tenants in capite were bound to the crown by personal loyalty and allegiance; the dignity of "him whom the king delighteth to honor" was upheld by royal grants. So we have a social structure in which the crown is upheld and supported by the tenants in chief, who, secured in their position and dignity by grants of land, are in turn upheld, formerly by villeins bound to the land-adscripti glebae-in later days by their tenantry, bound to them by tradition and personal loyalty, and over whom they exercise a traditional and personal protection and surveillance. The entire political mechanism was based upon land, and the personality and identity of the tenants in chief in their relation both to the crown and to the base tenantry were an essential element thereof. Hence any alienation of land out of the family was discountenanced by public policy, for it destroyed the traditional and personal relation of the tenant in chief to the crown and the tenantry and had so far weakened the social fabric; and if such alienation might be made, public policy demanded that the alienor should receive an exact quid pro quo, in order that he, whose traditional duty it was to support the crown, might have the means and ability to do so. Hence arose the rule that the consideration must be full and adequate.

That the public policy underlying this rule is the policy of maintaining landed estates in families is abundantly recognized by the courts of England. "I apprehend that the protection of the court with regard to reversionary interests was first from its tenderness towards real property thrown round expectant heirs," said Lord Hatherly in Tyler v. Yates, (L. R. 6 Ch. $665 ; 1878$ ); and again in O'Rorke v. Bolingbroke, (L. R. 2 App. Cas., 814; 1877), he said: "It sufficiently appears that the principle on which equity 
originally proceeded to set aside such transactions was for the protection of family property."

In cases decided while the social conditions were such as we have outlined, we find the point frequently urged that the severity

In Cole v. Gibbons (3 P. Wms., 290), decided in 1734, Lord Talbot observed that it was "The policy of the nation to prevent what was a growing mischief to ancient families, that of seducing an heir apparent from a dependence on his ancestor who probably would have supported him, and by feeding his extravagancies, tempting him in his father's lifetime, to sell the reversion of that estate which was settled upon him, forasmuch as this tended to the manifest ruin of families, therefore the policy of the nation thought fit (though it at first prevailed with some difficulty) to put a stop to so mischievous a practice by setting aside all tinese bargains with young heirs."

"This doctrine appears to be founded in part on the policy maintaining parental authority and preventing the waste of family estates, $* * *$ and in part on the equity of protecting against the designs of that calculating rapacity which the law constantly discountenances, the distress frequently incident to the owners of profitable reversions and the improvidence with which men are commonly disposed to sacrifice the future to the present." Reporter's note to Davis v. Duke of Marlborough, 2 Swan, I08.

"One ground on which the Court emphatically and through a long series of cases discouraged such transactions. was because they enabled the heir to destroy the family estate behind the back of those interested in seeing it preserved, in order to gratify his caprice or supply the necessities created through his caprice." Tynte v. Hodge, 13 Wkly. Rep. 172.

"As to the hazard which the purchaser ran: I have said that this Court have always extended their relief in such cases and with the greatest justice in the world for the sake of the public to prevent peoples gaining, as it were, to the prejudice of young improvident persons and the ruin of families." Lord Chancellor Hardwicke in Barnardiston v. Lingood, 2 Atk., ro3.

"The ill tendency of heirs contracting with strangers to furnish their wants is to make them quit a regular family life and dependency, to withdraw from advice and counsel of friends and to have youth supplied with the means of gratifying their passions, and the bringing of people together on the wotst principles on which men may contract, avarice on one side, and a craving appetite on the other. The greediness of gain is the only principle on which a stranger can be induced to furnish a stranger; and the occasion of applying to a stranger is, because the wants are such as he would not reveal to his family, which tends to a delusion in what is of general concern, the provision for posterity. A man may be giving his estate to a money-lender instead of the person intended; and every one disguising the truth from a man who has a right to the truth, is wrong, and ought not to be encouraged; and by this delusion he gives his estate to strangers. when he thinks he is giving to his heirs or relations, and when, if he had known the truth, he would have provided for that heir or relations, so as to prevent his beggaring himself. This has been a growing practice to supply young heirs, and the Court has extended its remedy." Burnett, J., in Chesterfield v. Janssen, 2 Ves. Sr., I24. 
of the rule operates as a hardship on the expectant; that if a full and adequate consideration be essential to its validity it will be next to impossible for him to find a purchaser. But we find at that time, that this result is in the mind of the judges one of the chiefest recommendations of the rule. It is with them purely a question of public policy, which rises superior even to the needs of the heir. In the year 1716 we find Lord Cowper in Twistleton v. Griffith, I P. Wms. 310, saying "that these bargains were corrupt and fraudulent and tended to the destruction of heirs sent to town. for their education and to the utter ruin of families; and that the relief of the court ought to be extended to meet with such corrupt bargains and unconscionable practice. $* * *$ His Lordship added, he saw no inconvenience in the objection that at this rate an heir without difficulty could not sell a reversion. This might force an heir to go home and submit to his father, or to bite on the bridle and endure some hardships and in the meantime he might grow wiser and be reclaimed." "

A CHANGE OF POLICY PRODUCED BY A CHANGE OF CONDITIONS.

But we find towards the beginning of the nineteenth century the political fabric of England undergoing a marked change. Commerce has attacked and overthrown feudalism and land is no longer the basis of the social structure. We find now a manufacturing community and the great mass of the people deriving their sustenance from the factories, not from the land. The crown has lost the power which it possessed under the feudal system; it has become an emblem, not a repository of sovereignty. The personal loyalty and support of the tenants in capite to the crown are no longer essential to the support of government; nor is the welfare of the masses dependent upon the personal care and surveillance of the landlard.

The alienation of lands now no longer has an injurious effect upon the public weal. The soxereignty is no longer supported by the loyalty of personal retainers; nor is it essential that the estates of such retainers be jealously preserved: The element of personal

\footnotetext{
"The tendency of this doctrine to render all bargains with such persons very insecure, if not altogether impracticable, seems not to have been considered as operating to prevent its adoption and establishment, but, on the contrary, some judges have avowed that probable consequence as being to them the recommendation of the doctrine." Peacock v. Evass, I6 Ves. Jr. 512.
} 
relationship has been eliminated from the political structure, so that public policy ceases to demand its preservation.

And we find this change reflected upon the law. In the year I8Io Sir William Grant, M. R., decided Gowland v. De Faria, enunciating the rule, which strictly conformed to the equity precedent of the times, ${ }^{1}$ that a full and adequate consideration must be paid and that the rule governing contracts of this class is "an exception to the general rule, that for mere inadequacy of value a contract is not to be set aside." It was there held that the full consideration required was the present value of the reversion as calculated by an actuary - that is, an exact quid pro quo, the alienor receiving back in another form exactly what he has conveyed away. This we have already shown was strictly the public policy of those times, and this policy overrode the best interests of the expectant and the rights of the alienee. But public requirements and public policy change, and we find that the rule of quid pro quo vanishes.

In the year 1825 Sir William Alexander in Headen v. Rosher ( I M'Clel. \& Y. 89) thus commented on Gowland v. De Faria: "Notwithstanding the very great respect I entertain for the great judge who determined it, I cannot bring myself to adopt the principle which he is reported to have laid down there. *** The price agreed on and actually paid was, in my opinion, the utmost that according to every human probability could have been obtained. I do not dispute Mr. Morgan's valuation; but the price put by the actuary can never be procured in fact; the witnesses for the defendant prove it, and it requires no witnesses. The price set was the arithmetical value. Now no man will part with his ready money and all the advantages which the power over it confers in exchange for a future interest, without some compensation beyond the dry arithmetical value of it. To set this bargain aside would be, in effect, to decree that no valid bargain for a reversion can be made, except by auction; and I do not know how any other sale of such an interest can be sustained unless judges proceed on the same principle as I do. This would be a very inconvenient restraint on the power of the owners of such property."

Yet in 1827 we find a reversion to the rule in Gozoland v. De

${ }^{1}$ Nott v. Hill, 2 Vern., 167; Nott v. Johnson, 2 Vern., 27; Berny v. Pitt, 2 Vern., 14; Twistleton v. Griffith, I P. Wms., 310; Peacock v. Evans, 16 Ves. Jr., 512; Lord Chesterfield v. Janssen, 2 Ves. Sr., 124; Bowes v. Heaps, 3 Ves. \& B., II7, IIg. 
Faria, Sir John Leach, M. R., allowing it with a great reluctance in Hinksman v. Smith (3 Russ, 433): "Sir William Grant did not consider himself as laying down a new rule but as following the current of authority; and since that case, the rule has so far been regarded as settled law of the court, that although $I$ have upon more than one occasion judicially questioned both the principle and policy of the rule, ${ }^{x}$ yet it would not become this court to make a precedent in direct opposition to it."

Subsequently, in 1832 , in the case of Potts v. Curtis (1 Younge, 543) Lord Lyndhurst followed the rule in Headen v. Rosher, and it was also followed in Wardle v. Carter, 7 Sim., 490 . In 1834 in Bawtree v. Watson, 3 Myl. \& K., 339, another reversal occurs and the rule is enunciated "that the purchaser of a reversionary interest, in order to support its title, must establish that the price paid was a full consideration."

In I840 Lord Chancellor Cottenham in Earl of Alborough v. Trye ( $7 \mathrm{Cl}$. \& Fin., 436) and in 1852 Lord Justice Cranworth in Edwards v. Burt (2 De G. M. \& G., 55) declared for the fair market price. But within the next ten years a decided reversal to the rule in Gozeland v. De Faria occurred in five cases decided by Sir John Romilly, ${ }^{2}$ which led Vice Chancellor Stuart to remark, in Willoughby v. Brideoke (I3 Wkly. Rep., 515): "The law on the subject of the sale of reversionary interests by private contract, as it is to be gathered from the later authorities, is to be read with great regret. The case of Edzerards $v$. Burt as decided by the lords justices (reversing the decree of the master of the rolls in favor of the defendant) has necessarily produced a series of decisions, the logical climax of which is found in Foster $v$. Roberts, where the master of

\footnotetext{
"The principle and-policy of this rule may be both equally questionable. Sellers of reversions are not necessarily in the power of those with whom they contract, and are not necessarily exposed to hard terms; and persons who sell their expectancies and reversions from the pressure of distress are thrown, by the rule, into the hands of those who are likely to take advantage of their situation; for no person can securely deal with them." Sir John Leach in Shelly $v$. Nash, 3 Madd., 232 (1818). "The plaintiff's counsel first insisted that he was entitled to be relieved on the ground of the purchase being of a reversion, unless the defendant could show that the purchase was for an adequate consideration. The policy of this rule as to reversions may well be doubted." Sir John Leach in Wood v. Abrey, 3 Madd., 417.

'Boothby v. Boothby, I5 Beav., 212 (1852); Salter v. Bradshaw, 26 Beav., 16r (1858); Foster v. Roberts, 29 Beav., 467 (1860); Jones v. Ricketts, 3I Beav., 130 (1862); Nesbit v. Berridge, 32 Beav., 282 (1863).
} 
the rolls says that according to the present doctrine of the court, unless a person gives much more than the value, it is impossible to purchase a reversionary interest with safety, except under a sale by auction. That is the result of the decision in Edzrards v. Burt; it is a result shocking to the understanding of every lawyer and man of sense."

THE STATUTE 3 I VIC., CH. 4, DECLARATORY OF THE NEW COMMON LAW.

We believe that the decisions of Sir William Alexander and Lord Lyndhurst were directly inspired by the change in public conditions, at that time most noticeable, but they were not strong enough to withstand the weight of the precedent of centuries and were overwhelmed. The changed demands of public policy were, however, recognized by Parliament, and in the year 1867 an act was passed "to amend the law as administered in Courts of Equity with respect to sales of reversions," (3I Vic., Ch. 4), in which it was enacted that "No purchase made bona fide and without fraud or unfair dealing of any reversionary interest in real or personal estate shall hereafter be opened or set aside merely on the ground of under-value." This act was but the legislative recognition of the fact that public policy no longer demanded that the condition and state of the landed families should be maintained. It established the law exactly as it was declared by Sir William Alexander in I825.

THE EFFECT OF THE OLD PUBLIC POLICY ON THE MODERN LAW.

The presumption against the validity of these contracts arose naturally and solely from the public interest in them, but so directly did the presumption operate for the benefit of the expectant, that we frequently find that result mistaken for the reason of the rule. The social structure has gradually changed and public policy has been modified accordingly. The public being no longer interested in the maintenance of the status of the tenant in chief, the right to sell is simply a personal one in which public policy is not concerned. But equity has not forgotten the beneficent result of the old rule to the expectant. The benevolent habit is not easily shaken off. He is still sheltered and protected and the presumption against these contracts is still maintained, but now, not for the benefit of the public but of the expectant. That which was once an incident has become an end, and he who would enforce the contract must show that he exercised no fraud, oppression or undue advantage in its 
procuring, and that the expectant received the best price obtainable in reason. As we have already quoted: "I apprehend that the protection of the court with regard to reversionary interests was first from its tenderness towards real property thrown round expectant heirs." (Tyler v. Yates, L. R., 6 Ch., 665.) This gradual shifting of the favor of the presumption from the public to the expectant was undoubtedly produced in large measure by a long line of decisions in which a young and profligate heir has squandered away his patrimony in vice and excess, has fallen among thieves and money lenders and has sold his birthright for a mess of pottage. The disadvantage of his position in making such conveyances appealed strongly to equity.

But throughout all these cases we find the expression that equity avoids such contracts in cases of disadvantageous position of vendor, fraud, oppression and undue advantage, on the ground of public policy. ${ }^{2}$ This expression is confusing, misleading and inaccurate. Public policy and the policy of the law are not synonymous terms. The term policy of the law is a synonym of justice and natural equity. Public policy is called into play only when the relief sought to be obtained is a menace to public security, although just and fair as between the parties to the controversy. In cases where such circumstances appear, it is unfair and inequitable to the individual to enforce the contract, but such a decree would not threaten public security. Relief is granted under the general policy of the law, under the ustral rules of equitable jurisprudence, in cases of actual or constructive fraud. ${ }^{2}$

${ }^{2}$ Tuistleton v. Griffith, I P. Wms., 310 (1716) ; Barnardiston v. Lingood, 2 Atk., I33 (r740); Chesterfield v. Jarnssen, 2 Ves. Sr., I24 (1750); Peacock v. Evars, 16 Ves. Jr., 512 (1810) ; Shelly v. Nash, 3 Madd., 232 (1818) ; Davis v. Duke of Marlborough, 2 Swan., 108 (1819); Ryle v. Swindells, I M'Clell, $5 \mathrm{Ig}$ (1824) ; Bawtree v. Watson, 3 Myl. \& K, 339 (1834); King v. Hamlet, 2 Myl. \& K., 456 (1834); Earl of Aylesford v. Morris, L. R., 8 Ch., 484 (1873); St. Albyn v. Harding, 27 Beav., II (1879) ; Brenchly v. Higgins, 70 L. J. Ch., I88.

2"The relief is founded in part upon the policy of maintaining parental and quasi-parental authority and preventing the waste of family estates. It is also founded in part upon an enlarged equity flowing from the principles of natural justice." Story, Eq. Juris., Sec. 335 ; Wolmesley v. Booth, 2 Atk., $27,28$. 
THE RULE THAT THE PRESUMPTION IS AGAINST THE VALIDITY OF THESE CONTRACTS.

The only rule which public policy evolved in such cases was that of full consideration. As we have already shown, the policy of the crown demanded that the position of the crown tenants in whom it found its support should be maintained. Courts of equity, as prerogative courts (Story, Eq. Juris., Sec. 44), were peculiarly susceptible to the influence of the crown policy. Hence arose their "tenderness toward real property," and the ancient rule of full consideration applied in actions for specific performance of contracts to convey, entered into not only by the reversioner but by the tenant in possession. (Pomeroy on Contracts, Sec, 194.) As long as the rule of full consideration existed, the questions of disadvantageous position, fraud, etc., could not arise, for if the consideration were in fact full, such circumstances could not exist; if it were not full, the contract was invalid independently of their existence. It was only when the conditions changed and the rule of fair consideration sprang into being that these circumstances became material. The rule of full consideration carried with it, as a necessary and essential incident, the unusual presumption against the validity of the contract. Conditions changed, the public ceased to concern itself with such contracts, but the presumption remained, illogical, misplaced and abnormal. When this class of cases is considered apart from the corpus of the law, the presumption appears at first blush equitable, but its supporting reason is specious and inconsonant with the general rules of equity. Every day persons contract from positions of even greater disadvantage. The holder of unimproved land, burdened with mortgages and taxes, seeks to sell in order to discharge these debts. His condition is open, notorious and of public record. The prospective vendee has every advantage; yet from their positions does not arise any presumption of unfair dealing. The burden is on the vendor seeking to rescind to show fraud. The anomalous presumption can be explained only upon the one theory: that it was originally demanded by the public policy of feudalism. Reading these cases from the standpoint of to-day and in the light of history, it becomes apparent that the presumption is but a surviving fragment of a shattered system, a rule of which the reason is dead.

The doctrine of the expectant's disadvantageous position reaches its logical and most absurd climax in Bromley v. Smith (26 Beav., 
644; 1859), where Sir John Romilly, M. R., holds that the facts "that the plaintiff was a man of mature age and *** that he perfectly understood the nature and extent of the transaction, do not, whether taken separately or conjointly, disentitle the plaintiff to relief"; and in Tynte v. Hodge (I3 Wkly. Rep., 172; 1864), where Vice Chancellor Wood holds that "although Colonel Tynte was forty-seven years of age, and had had some considerable experience in borrowing money, nevertheless in an investigation of this description he must be regarded as the unprotected heir, whom the Court of Chancery always favored."

THE CAUSE OF ITS CONTINUANCE.

Why was this archaic presumption continued after public policy had ceased to demand it? Why does the law create a relation of trust and confidence between the expectant and his prospective alienee and not between one who contracts to sell his next year's crop and the intending purchaser? Why should it say that his position is presumptively disadvantageous and does not raise the same presumption in the case of all borrowers? Why does the law insist that the bargain must be advantageous to the expectant before it can be enforced and does not so insist in the case of other bargains? Why does the law create a relationship which does not in fact exist and presume that he who has bargained for a reversion has been guilty of fraud? The answer is clear. Because before the day of England's commercial activity, when the vast majority of landowners lived upon the land and from the land, when their sons were not seeking capital in order to engage in business, practically the only reason for raising money upon a reversion was to expend it in dissipation or to relieve a present necessity. The profligate and the man weighed down by necessity were certainly at a disadvantage in so contracting. It was a presumption of fact, based upon the common experience and observation of mankind in those days, that the alienor of an expectancy was in a position of disadvantage.

But with the increase of commercial activity, young men are at least as apt to attempt to raise money upon any security which they can give for the purpose of engaging in business and the serious pursuits of life as for the purposes of profligacy or the payment of burdening debts. Certainly to-day our common experience and observation raise no such presumption in fact, and it is with an absolute shock that we read that "although Colonel Tynte was 
forty-seven years of age, and had had some considerable experience in borrowing money, nevertheless in investigations of this description, he must be regarded as an unprotected heir."

THE RULE IS DISAPPEARING.

Has the law changed to conform to changed conditions? Is the presumption in favor of or adverse to such contracts? The note of change has been sounded in England. In the year 1871 in the case of Tylet $v$. Yates (L. R. 6 Ch., 665), Lord Hatherly said: "It was supposed that no person, whatever his age, was competent to deal with reversioners. The law, however, has been recently changed [3I Vic., Ch. IV], and it has been decided by the Legislature that these bargains shall be as free as others." And in 1875 Vice Chancellor Bacon said in Judd v. Green (45 L. J. Eq., N. S., I08): "It may be right that a needy, improvident youth who desires to raise money upon his expectancy for the purpose of discharging debts contracted in his nonage, or furnishing him with the means of indulging in luxury and extravagance, ought to be protected against the sordid and corrupt practices of persons who seek to make a profit out of such a man's inexperience. But this principle must be, as it has always been, applied with great caution, and it has never yet been held that an expectant heir was incompetent to deal with his interest for substantial purposes, or that the persons dealing with him could have their transactions impeached unless there was something immorally wrong so as to make it necessary to discountenance their dealings on the ground of public policy. * * * In this case the plaintiff * * * desired to raise money with which he might procure admission as partner to some established business. There is certainly nothing unlawful or imprudent in that. On his introduction to Hathaway his first object was to raise money, and his second to employ the money when raised in a proper, beneficial manner. I fail therefore to see how the fact of his youth, or his being entitled to an estate in reversion, can by themselves affect the case. If indeed he had been imposed on by the fraud and deceit of the persons with whom he engaged, that might entitle him to relief, but not other or more than he might have claimed whatczer might have been his age or whatever the nature of his interest."

But only recently (IgOr) Lord Justice Rigby said in Brenchly v. Higgins (70 L. J., Ch., 778) : "As I understand it, the law was that in dealing with expectant heirs (and the plaintiff in this case 
comes within that description) all persons, whether they were money lenders or not, were bound to show and had the onus thrown upon them of proving the absence of fraud or unfair dealing. I do not consider that this act of Parliament in the least alters that." See also Earl of Aylesford v. Morris (L. R., 8 Ch., 484; 1873).

Is this last case a reversal to the old rule or its dying flicker? Is the rule in Tyler $v$. Yates and $J u d d v$. Green a prophetic light which burns for a short time and then goes out, as did Headen v. Rosher? Will it necessitate a legislative act to establish these contracts on the same basis as all contracts for future sale? That the conditions of to-day demand such a rule, that the unhampered power of alienation of all possible assets and securities is a business necessity, cannot be doubted. That the tendency is towards considering these contracts presumptively fair and placing the burden of proving disadvantage of position, fraud, oppression and undue advantage upon those who would rescind them or oppose their performance is apparent. This tendency is irresistible. How long precedent and conservatism will prevent its unqualified recognition by the courts of England is problematic. Perhaps its full recognition can be secured only by act of Parliament, but none the less certainly it must come, because it is demanded by the conditions of to-day and by public policy, now in fact changed to conform to those conditions:

It may be interesting in this connection to note the old case of Nichols v. Gould ( 2 Ves. Sr., 423), decided in 175 I by Lord Hardwicke, in which the question of public policy and the resulting favor to the heir was not considered. This case stands quite apart from the decisions of that time and of many years later, but is interesting as a true expression of the law of such contracts when the question of public policy is eliminated, as we contend it is to-day. He said: "The plaintiff was a poor dragoon, entitled to a reversion in fee of a small estate after the death of a tenant for life; to whose first and every other son there was a remainder, but who then had no son nor was married. Defendant purchased this reversion; tenant for life died in about a month after. The bill was to set aside this conveyance as being at an under-value.

"There is no proof of any fraud or imposition on the plaintiff, nothing but suspicion, and therefore it is too much to set aside this purchase merely on the value. Every purchase of this kind must be on the foot of great uncertainty as to the value. *** Then will a court of equity, after the contingency has fallen out one way, enter into consideration of the value? If indeed there was any 
degree of fraud or imposition the court would come at it and set it aside; but there is none. The plaintiff was in the best situation to know the value, not being at a distance from the estate or from the tenant for life or his family. Looking on the event, it was purchased at an under-value; but had he lived longer and had children, it had been different. It is asked, Where is the harm, because defendant will have his money again? But I cannot set it aside without making him pay costs; and that argument might be made use of on every advantageous purchase, that he might have his principal and interest again. *** These kind of purchases are a sort of chance; it is too hard to come at it, unless there was any proof of fraud or imposition, which then the court would lay hold of. Let the bill be dismissed."

THE SOURCES OF THE RULE IN AMERICA.

In regard to the rule in America, we find it directly based upon Judge Story's work on equity jurisprudence. (Secs. 333-349). That the work of a writer of such pre-eminent ability should have fixed and established the law in this country is a matter of congratulation, not of complaint. But it is to be borne in mind that this work was written in the year 1835, when the doctrine of public policy and the rule of full consideration were still prevalent in England. This portion of the work was based entirely on the English case law; not a single American authority is cited in the original edition. Judge Story wrote of the law as he found it, yet, doubting the policy and principle of the rule which fixed the presumption against the validity of the contract, quoting with approval Sir John Leach's dictum in Shelley $v$. Nash. (Sec. 338.)

THE PUBLIC POLICY OF ENGLAND AND AMERICA COMPARED.

We have shown that the attitude of equity in regard to these contracts has since Judge Story's time undergone a marked change in England, due to changed conditions. Judge Story wrote only of the law of England. The conditions which produced the rule in England have never existed in America. The public policy of this country has never favored the retention of landed estates in families, but has treated land as the subject of trade and encouraged its facile alienation. The social conditions in America have never been such as to engender the presumption of profligacy or debt from the fact that an expectant endeavors to raise money on his expectancy. As Judge Story himself wrote: "Sellers of reversions 
are not necessarily in the power of those with whom they contract, and are not necessarily exposed to imposition and hard terms." (Story, Eq. Juris., Sec. 338.) The cases decided in this country are few in number, and follow without question the English precedents of the eighteenth and early nineteenth centuries. In all of them the guidance of that deus ex machina, Public Policy, is invoked, but in none of them is it considered what is the public policy of to-day and of America towards these contracts. What is its basis? What is its reason? The policy of our people and our times should control the law of such contracts in this country-not the policy of mediæval and feudal England.

Thomas H. Breeze. 